\title{
When Workers Had Security
}

\author{
By A. M. PIPER \\ Editor Council Bluffs Nonpareil
}

The quest for security is one of the outstanding features of the present era. For at least 20 years there has been a growing belief that a comparatively riskless and secure existence is possible with little or no effort on the part of the individual.

Today millions of people are convinced that in some magic and mysterious manner the government can assure them a livelihood and a care-free and comfortable old age. They think a new system has been discovered and perfected-a system that will assure them good jobs at good pay, good homes to live in, medical care, hospitalization when they are ill, old age security.

The fact of the matter is there is nothing new about this program. The world had such a system between the 12th and 15th centuries. History refers to it as feudalism. It gave the common man everything he needed, according to the standards of that day, except the opportunity to do as he pleased.

Workers were bound together in tight organizations called fraternities. Full employment was accomplished by seeing to it that the work force should be just large enough to do the work that had to be done. Only enough workers were taken into the fraternities to replace those who died or retired from old age.

Employers were organized into guilds, as the workers were organized into fraternities. They sought security for themselves by restricting competition, fixing prices, controlling quality and limiting output. There was almost perfect co-operation between employers and employes. Strikes were practically unknown.

Believe it or not, 500 or 600 years ago the common 
man had everything today's reformers think the common man wants. He hadn't any worries. His fraternity wardens prevented anyone from outproducing anyone else. The prices he paid for things were fixed and all price adjustments were accompanied by wage adjustments. The medieval worker received enough to live on 12 months out of the year. He didn't have to work overtime. He had a profit-sharing plan, a pension plan and old-age security. Employers were restrained by law from exploiting their workers, who were often protected from arrest and imprisonment.

Why, then, did this utopia come to an end? It ended because personal ambition was not taken into consideration, and many of the benefits of the system were at the expense of those not in it. The feudal system, in creating security, had to remain static. It couldn't grow or change.

Individuals outside the system began to develop new industries. A mercantile revolution occurred in the course of which workers began to progress according to their own abilities. Ambitious workers actually set up their own industries. Many failed, but some succeeded. In the end, the urge to progress and expand won out. The feudal system, which gave its members a kind of security, disappeared.

Security is a good thing to want, but a bad thing to have, because it inevitably prevents change. And without change there can be no progress. Today's seekers after security would do well to read the history of the middle ages.

\section{"Hawkeye Tales"-a History}

A remarkably good piece of historical work has been done by Hubert L. Moeller, superintendent of the Radcliffe public schools. He has written and published a condensed history of Iowa for use in the public schools that is concise and informative, considering its brevity. 
Copyright of Annals of Iowa is the property of State of Iowa, by \& through the State Historical Society of Iowa and its content may not be copied or emailed to multiple sites or posted to a listserv without the copyright holder's express written permission. However, users may print, download, or email articles for individual use. 